\section{Finite Element Method analysis for mechanistic design in flexible pavement, Review: From how to build a material in FE analysis to complexity in reality}

\author{
Seoyoung CHO - Department of Highway and Railway Engineering, \\ Budapest University of Technology and Economics - hotaru128@hanmail.net \\ CsabA TÓTH - Department of Highway and Railway Engineering, \\ Budapest University of Technology and Economics
}

ZoLTÁN SOÓS - Department of Highway and Railway Engineering,

Budapest University of Technology and Economics

Érkezett: 2018. 07. 16. - Received: 16. 07. 2018. - https://doi.org/10.14382/epitoanyag-jsbcm.2018.35

\begin{abstract}
There are plenty of applications of finite element methods (FEM) in various fields. FEM itself stands strong in the field of structural analysis and the trend of applying it into asphalt pavement is widespread. As the mechanistic analysis becomes an important part of pavement design for the estimation of its structural response, FEM in terms of precise mechanical design became one of a strategic tool. Hereinafter a short overview of FEM adapted flexible pavement design field will be introduced. The main focus will be on how the material model for each layer of pavement structure is embodied in FE modeling. The aim of this overview is to show a stream of FEM application in flexible pavement design and call an attention to its potential. A strong point and shortcoming will be introduced as well, and try to reflect recent trends.

Keywords: finite element method, asphalt pavement analysis, material model
\end{abstract}

Seoyoung CHO, PhD Student PhD student at Budapest University of Technology and Economics.

Csaba TÓTH PhD, MBA Member of the Hungarian Chamber of Engineers, the Hungarian Scientific Association for Transport and the Hungarian Road Society. Worked as Head of Division at Csongrád Couty Road Administration, then ÁKMI Kht. Involved in quality control of Hungarian road developments and both national and international researches as part of the Strabag concern. Had a role in severa road overlay projects as engineering expert, designer and supervisor. Currently Assistan Professor and Head of Asphalt Unit at the Pavement Laboratory. Research field includes load bearing capacity of road structures and overlay design of flexible pavements.

Zoltán Soós, PhD

Obtained $\mathrm{PhD}$ in pavement design at Department of Highway and Railway Engineering, BME. Member of the Hungarian Scientific Association for Transport. Research topics include testing and design of asphalt pavement materials and road structures with emphasis on fatigue behaviour and service life, performance and structural design. Takes part in lecturing at the University and as Deputy Head, in the work of the Pavement Laboratory since 2015.

\section{Introduction}

For decades, the multilayered elasticity model is widely used in pavement structure analysis. Software based on multilayered elastic model such as ILLIPAVE, MICHPAVE and EverStress are easy to use, however, granular material of pavement structure shows nonlinear behavior that is there is a need of mechanistic analyses which can deal with this characteristic. FE method can be powerful tool for this thanks to its user define element command. Not only the measurement of critical response can be done easily by FE program, but also it helps analysts to build a stress-dependent material model by editing some part of codes so FEM can be distinguished from existing multilayer elastic analysis programs.

As the design concept of Mechanistic-Empirical design on pavement design was introduced, there are the various tool for supporting mechanistic design also become widespread. Representatively, Finite Element (FE) Method is one of the tool for mechanistic design. Since the commercial FE analysis solution contains constitutive equations in itself, the FE method could be used in pavement design to model the viscoelasticity or anisotropy. However, commercial FE solutions do not fully support nonlinear analysis of pavement design like stress dependent strength in each layers, and not suitable for the purpose of investigating material properties. Thus in recent days researchers are trying to involve this nonlinearity into analysis in their own codes.

Here the followings are about those codes in time series. Tried to introduce essential process during development of numerical model and the background of FE analysis in pavement design.

\section{Constitutive equations of pavement layers}

Pavement is composite with layers, which are having different material property from each other but work together to move as a one structure so it makes analysis be difficult. The essence of analysis is to verify each layer's response to depict the behavior of whole pavement structure. FE is the tool for this verification. Followings are well known constitutive equations for each layer.

\subsection{Asphalt concrete surface layer}

The dynamic modulus measured over various temperature ranges and load cycles can be converted into master curves that represent the physical properties of the asphalt concrete for pavement thickness design and for the performance analysis.

Most of case asphalt binder and mixture is affected by temperature and loading frequency. These material properties cause those bituminous layer displays viscoelasticity. As a strength parameter of these bituminous material's property, dynamic modulus $\left(E^{\star}\right)$ is used:

$E^{*}(t)=\frac{\sigma_{0}}{\varepsilon_{0}} e^{-i \varphi}=\left|E^{*}\right| e^{i \varphi}$

This complex modulus is a function of stress and strain amplitudes $\left(\sigma_{0} ; \varepsilon_{0}\right)$, phase angle $(\varphi)$, angular frequency $(\omega)$ and imaginary number.

Bituminous materials like asphalt mixture displays time dependent mechanical behavior. A Huet-Sayegh model describes response of bituminous material. This mathematical representation can simulates the behavior of asphalt mixes 
in cycling tests in wide frequency range [1]. This model is implemented as a rheological model which employs additional dashpot in series along with spring elements (Fig. 5). Mathematical expression of Huet-Sayegh model is below, Eq. (2). $G^{*}(\omega)=G_{0}+\frac{G_{\infty}-G_{0}}{1+\delta_{1}\left(i \omega \tau_{1}\right)^{-m_{1}}+\delta_{2}\left(i \omega \tau_{2}\right)^{-m_{2}}}$

Eq. (2) indicates a shear modulus in Huet-Sayegh model in frequency domain. $G_{0}$ is rubbery shear modulus, $G_{\infty}$ is instantaneous shear modulus. $\tau_{1}$ and $\tau_{2}$ are parabolic dashpot's time constant, $m_{1}, m_{2}, \delta_{1}$, and $\delta_{2}$ are model parameters.

\subsection{Subgrade}

Subgrade modulus shows a stress-dependency on its modulus, thus the modeling of it includes the modulus values assigned to any element are related to previously computed values of stress for that element [2], [4].

It is known that subgrade modulus $\left(\mathrm{M}_{\mathrm{r}}\right)$ is the key factor which controls the surface deflection in flexible pavement since base course layer modulus and asphalt surface modulus have minor effect on surface deflection compare to effect of subgrade modulus [22]. Among the intense studies on constitutive models of subgrade, followings are the roots of widely used ones until now (Table 1). Main features of those models is that it contain stress state; principal stress $\left(\sigma_{3}\right)$, bulk stress $(\theta)$, deviatoric stress $\left(\sigma_{\mathrm{d}}\right)$ inside the modulus $\left(\mathrm{M}_{\mathrm{r}}\right)$.

\begin{tabular}{lc}
\multicolumn{1}{c}{ Model name } & Subgrade modulus \\
Confining model [4] & $\mathrm{M}_{\mathrm{r}}=\mathrm{k}_{1}\left(\sigma_{3}\right)^{\mathrm{k}_{2}}$ \\
\hline $\mathrm{K}-\theta$ model [5] & $\mathrm{M}_{\mathrm{r}}=\mathrm{k}_{1}(\theta)^{\mathrm{n}}$ \\
\hline Uzan model [6] & $\mathrm{M}_{\mathrm{r}}=\mathrm{k}_{1}(\theta)^{\mathrm{k}_{2}}\left(\sigma_{\mathrm{d}}\right)^{\mathrm{k}_{3}}$ \\
Table 1. Subgrade modulus models & \\
1. táblázat & Modellek az alapréteg modulusának meghatározására
\end{tabular}

The models shown in Table 1, $\mathrm{M}_{\mathrm{r}}$ is related to stress state in complicate relation. FE method is practical to predict stress states with accuracy and includes those stress state got from the formal analysis step to following analysis step instantly.

\section{FE model}

The pavement is a layered structure and the load applied is delivered on the AC surface to the underlying layers. Thus the modeling of the pavement structure is to set element data for each layer and consider all layers acting as whole one structure. Fig. 1 describes the cross section of numerical model, and positioned the critical point where the plastic distress occurs. Geometry and load configuration look simple to model, but there is a complexity on modeling realistic behavior of computation.

From the studies researchers found that granular materials of pavement structure exhibits stress-dependency that is resilient behavior. FE programs that analyze pavement structures need to take into account this nonlinearity resilient characterization to make much realistic analysis.

The difference in behavior between a homogeneous (elastic half system) and a layered system modeled by FE method is shown in Fig. 3, where the contributions to surface deflection are functions of depth beneath the surface. It shows that the contribution of the material in deep part plays an important role on the deflection in multi-layer system than the half-space [6], [12]. This analysis shows the awareness of effect on surface deflection of sub-layer is important, and has to guarantee enough depth but does not exceed length-to-width ratio five to one.
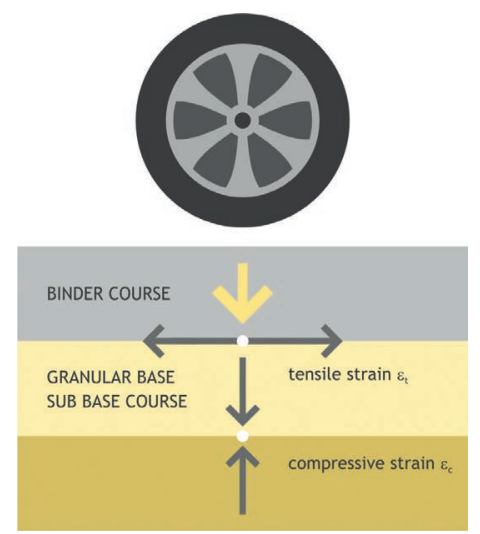

Fig. 1 Typical cross section of pavement with critical locations [19]

1. ábra A pályaszerkezet kritikus feszültségeinek típusa és helyzete [19]

In terms of convenient and accurate analysis, the former ones are suitable with relatively simple inputs. The latter ones are for realistic analysis but requires analysts a period to be skilled. The result may differ from the analysts because the assumptions on inputs during modeling process are up to analysts. There guidelines exist to avoid individual error and set a ready-to-use input guide [1]. Followings are the introduction of studies to set a subjective input variables.

\subsection{Material modeling}

Material selection in FE modeling is the crucial process. To build more realistic numerical model, the proper material selection has to be followed. There are the isotropic and anisotropic material models which can be modeled by differ the horizontal and vertical elastic modulus. Since the soil particle is not a regular shaped, considering the anisotropic properties of materials during modeling can be sometimes needed.

Anisotropic properties of materials have no significant effect on the magnitude of pavement displacement under traffic loads, while have significant effect on the magnitude of tensile strain. However, in terms of service life there is no significant difference between isotropic and anisotropic models [18]. Fig. 2 shows the differences in the tensile strain at the bottom of the asphalt layer between isotropic model and anisotropic model (where, $\mathrm{n}=E_{h} / E_{v}$ ).

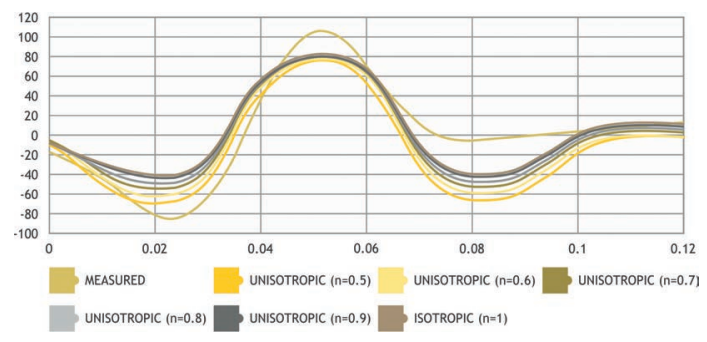

Fig. 2 Comparison between measured and calculated longitudinal strain at the bottom of the wearing surface [18]

2. ábra A mért és számított vízszintes húzófeszültség közötti összehasonlitás a kopóréteg alján [18] 
Another material model to decide is to determine whether the model will be linear or nonlinear. A thing to be cleared is that thanks to resilient behavior of pavement, it is enough to set up model system with an elastic constitutive relationship. The fact that well known is that granular materials and subgrade soils performs non-linear resilient behavior which is varied by level of stress.

Most of time the design of pavement stress is based on multilayered elasticity theory, however, disadvantage of this theory comes from its assumption; each layer is homogeneous throughout the layers. In particle level, material behaves in nonlinear way and if the model neglects this nonlinearity then it cannot have much realistic results. FE programs are used to solve this shortcoming by combining the material models; until now $\mathrm{K}-\theta$ model and bilinear material model is used for granular layer to reflect this nonlinearity. The effect of nonlinearity of base course is reduced as the elastic modulus of surface course increases [10], [23].

The model with consideration of dynamic analysis, viscoelasticity and nonlinearity, and temperature gradient lies along field data whereas simple model assumption produces high errors especially when the viscoelasticity of asphalt mixture was not considered [10].

As one of the powerful feature of FE program is that analysts can use user define material subroutines. With this subroutine, evaluation of interlayer is available which makes FE model much more realistic. There is a study which employs spring element (partial bond) and set different spring constants in different directions of axes [11]. The whole pavement structure is layered and is the layers are not fully (asphalt layers), or not bonded at all (granular layers). By using user define material models, modeling of this kind of partial boding condition is possible [5].

It is well known that a comprehensive analysis of flexible pavements should include the stress-dependent behavior of granular base course and the cohesive subgrade, finite width of the AC pavement, multiple wheel loading at any location of the given domain being analyzed, and partial bonding between the AC and the granular layer [5]. The challenge in the modeling of asphalt mixture contain the highly heterogeneous nature including aggregate internal structure and air void distribution, the time, temperature and rate-dependent behavior of the matrix and the limited computation capacity for very precise prediction [23].

A non-linear and time dependent analysis by FE method, literatures suggests to use a time depend materials. By taking step by step analysis the time dependent problem is solved. In this time interval, stress has to be constant and this interval has to be small enough. The viscoelastic pavement model; use the concept of simulating the partial bond condition between the asphalt and the base layer [11]. Time histories of strains or creep stiffness of creep tests are needed to simulate viscoelastic responses of asphalt material [14].

\subsection{Mesh}

The most time and effort consuming part is mesh generation in FE analysis. The mesh size is directly related to the accuracy of the results, and the cost of analysis. Fine mesh produces much more accurate result compared to coarse mesh but not always the finer mesh is adequate since there is a certain level that suits the accuracy and economy at the same time. Designers are intensively trying to find such level and build criteria for it.

Computed stress accuracy is related to mesh in vertical direction and deflection is related in horizontal direction mesh. Vertical extent of finite element mesh dominates convergence of stress [11]. The selection for the element sizes is based on the mesh convergence analysis.

The degree of mesh refinement is an important factor in estimating an accurate stress filed in the pavement. The mesh construction, mesh refinement, element aspect ratios and material non-linearity affect the overall time efficiency. For the three-dimensional problems, a careful balance is required to meet the demands of solution time and memory without sacrificing accuracy [13].

In the pavement analysis, mesh size determination is an important matter of fatigue crack analysis. Traffic flow is usually modeled as an axle fatigue load with equivalent fatigue damage. FE method is useful to determine the reference stress for fatigue life estimation and at the same time investigation of interaction between pavement and bridge deck [3]. So that it helps to decide the allowable stress level of pavement structure.

\subsection{Load and boundary condition}

Tire contact pressure is modeled as a uniformly distributed load in circular or rectangular area, see Fig. 3. The selection of analysis model is also one of the factor that influences on analysis result. Designers can choose between statistical analysis and dynamic analysis. Statistical analysis is economically effective and reliable but the dynamic analysis reflects much more realistic effect on model.

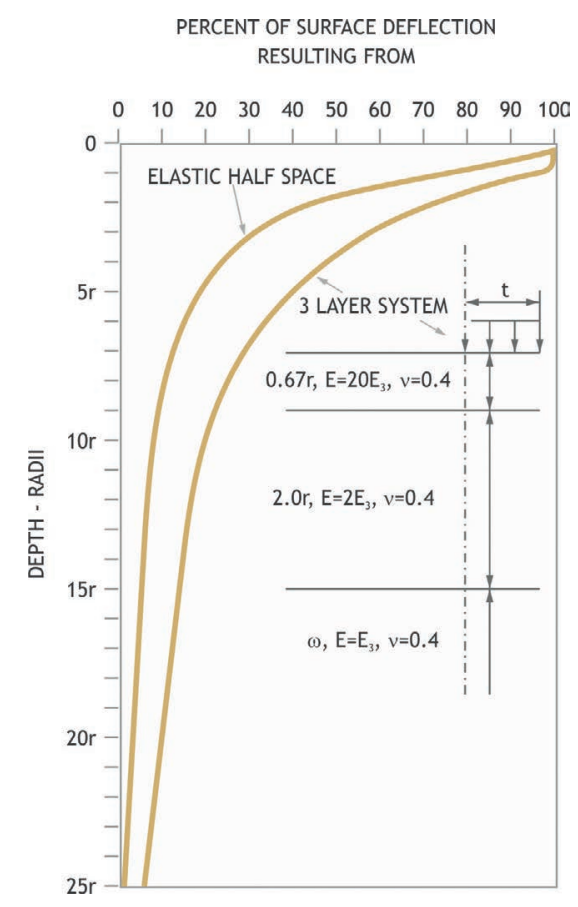

Fig. 3 Comparison of surface deflections of elastic half-space and layered system [6]

3. ábra A rugalmas féltérben és többrétegü rendszerben létrejövö behajlások összehasonlítása [6] 
Most of cases tire pressure is modeled as a contact stress at the area where the tire is standing on pavement surface and is to be a distributed load on a contact area. The contact area can be modeled as a circular shape or rectangular shape, and in the case when contact is modeled in rectangular shape it is guided to have a dimension of BX0.7B. The moving tire can be embody as an imprint area to represent a smooth pavement surface [8], [9].

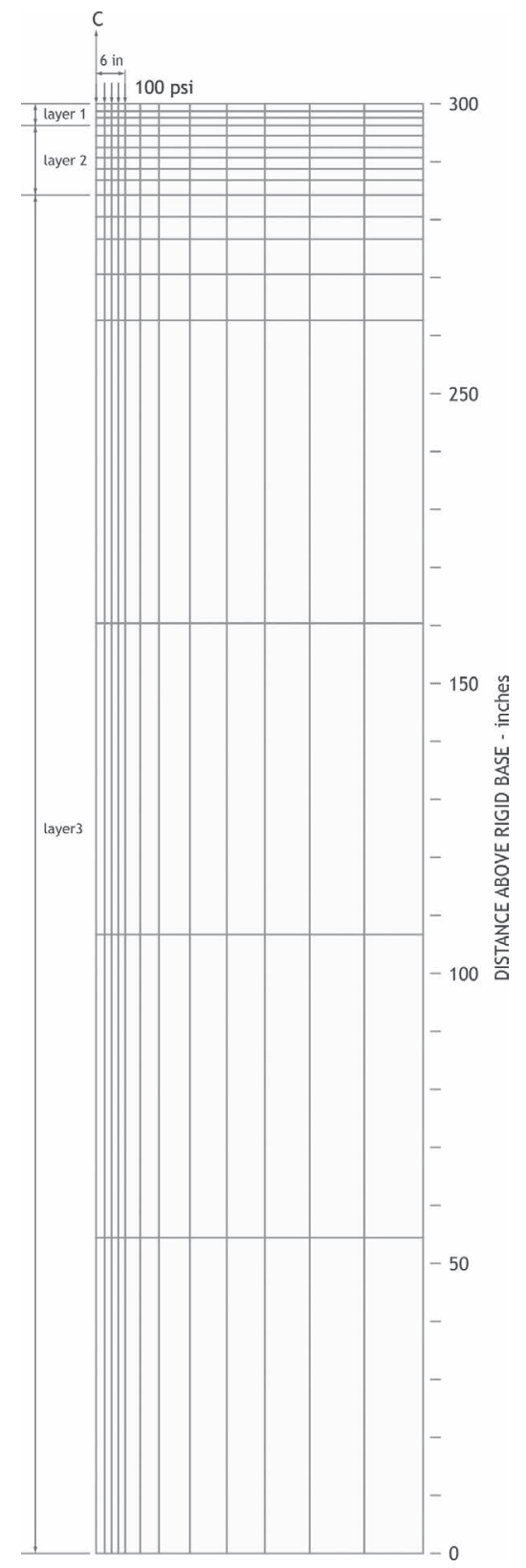

Fig. 4 Finite element configuration used for analysis of layered system-deep bottom boundary [6]

4. ábra A többrétegü rendszer elemzéséhez használt véges elemes összeállitás [6]

There are two types of thermal strains which are interesting in mechanistic design. One is thermal gradient and the other one is uniform thermal strains. The formal one happens because of the temperature change in a day, and the latter one is because of temperature change due to seasons. In the FE modeling, the thermal load can be modeled by applying gravity load in separate time step and propagate gravity load to get a thermal gradient profile [18], [17], [7], [16].
Hooke's linear elastic model is used for mechanistic analysis and design of asphalt pavement structures. It is considered to be appropriate for determination of response of asphalt layers at lower temperatures [19].

The rheological behavior directly connected to deterioration and determine the thickness of layers. Bituminous materials like asphalt mixture displays time dependent mechanical behavior. A Huet-Sayegh model, Eq. (3) describes response of bituminous material. This mathematical representation can simulates the behavior of asphalt mixes in cycling tests in wide frequency range [1]. This model reflect the time lag between stress and response due to the viscoelastic behavior of bituminous asphaltic material in pavement structure. Burger, Maxwell, and Kelvin models are included in mechanical model for viscous material as well, however they have constrain that they do not fully draw complex behavior of asphalt concrete. Whereas Huet-Sayegh model has shortcoming which does not reflect irreversible deformation properly compare to those models (Fig. 5).
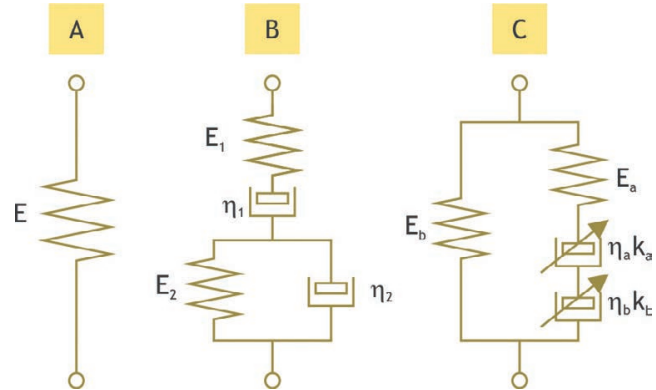

Fig. 5 Rheological models of the materials of asphalt layers: A) Hooke's elastic model, B) Burgers' viscoelastic model, C) Huet-Sayegh's viscoelastic model [15]

5. ábra Az aszfaltrétegek anyagainak reológiai modelljei: A) Hooke-féle rugalmas modell, B) Burgers-féle viszkoelasztikus modell, C) Huet-Sayegh-féle viszkoelasztikus modell [15]

To account for the variation in the modulus of elasticity with depth within a layer, the layer should be divided into several sublayers and the modulus should be gradually varied between the layers.

To numerically solve a boundary value problem that involves boundaries extending to infinity (e.g. subgrade), the domain must be truncated at a reasonable distance from the loads. For this reason, the size of the computational domain and the effects of the boundary conditions at the truncated remote boundaries has to be carefully studied [20], [11].

Subgrade layer is modeled to be infinite in vertical direction. Take into account the computation time and cost, the size of domain has to be determined. For the analysis of structure, set the proper boundary condition is crucial part in modeling. In 1968 there was a study which verified boundary condition that produces accurate results is to set fixed boundary at a depth about 50 radii and constrained from moving in radial direction about 12 radii from the center when the FE model is under circular distributed load [2].

A model which is large enough can avoid the boundary effect. To determine the domain size differs from designers and this step is comparison of structural responses when boundary position is 10 to 50 times from the center of symmetry. A research suggests a general criteria for circular distributed load, designers to use a domain 150 times bigger than loading radius [21]. 


\section{Conclusions}

This is a very short review about the concerns and choices when do the modeling with FE software. There are more and more demand for accurate analysis to save design cost and ensure structure integrity during its service life. Now the design trend is changing empirical method into MechanisticEmpirical method for that purpose. Along with mechanisticempirical analysis, various mechanical model is verified and applied in the FE method in a user define element command.

From the choice of proper material model to set proper mesh size and boundaries are all done by analyst in FE analysis. All of the stages in modeling process a series of selection is continued and it makes whole design process be dependent on analysts. These selection problems make modeling be difficult and complicated. To overcome, many researchers carry out a sensitivity tests to verify and choose which parameter is crucial and has impact on the response. In closure, there is a need to catch up the gap between numerical models which can overcome the complexity in real behavior due to mechanical interaction in each layers.

\section{References}

[1] AASHTO, (2008): Mechanistic-Empirical Pavement Design Guide. Washington DC: American Association of State Highway and Transportation Officials. ISBN; 978-1-56051-597-5

[2] ABAQUS, (2014): Standard user's guide. RI, USA.: The Abaqus Software is a product of Dassault Systèmes Simulia Corp.

[3] Bohai, J. et al., (2013): Evaluation on root-deck fatigue of orthotropic steel bridge deck. Journal of Construction Steel Research, Volume 90, pp. 174183. https://doi.org/10.1016/j.jcsr.2013.07.036

[4] Chen, D. H. - Zaman, M. - Laburos, J. - Soltani, A. (1995): Assessment of Computer Programs for Analysis of Flexible Pavement Structure, Washington D.C.: Transportation Research Board of the National Academy of Sciences.

[5] Chun, S. - Kim, K. - Greene, J. - Choubane, B. (2015): Evaluation of interlayer bonding condition on structural response characteristics of asphalt pavement using finite element analysis and full-scale field tests. Construction and Building Materials, Volume 96, pp. 307-318. https://doi.org/10.1016/j.conbuildmat.2015.08.031

[6] Duncan, M. J. - Monismith, C. L. - Wilson, E. L. (1968): Finite Element Analyses of Pavements. Highway Research Record, Volume 228, pp. 18-33.

[7] El-Maaty, A. E. A. - Hekal, G. M. - El-Din, E. M. (2016): Modeling of Dowel Jointed Rigid Airfield Pavement user Thermal Gradients and Dynamic Loads. Civil Engineering Journal, 2(2), pp. 38-51.

[8] Faheem, H. - Hassan, M. (2014): 2D plaxis finite element modeling of asphlalt concrete pavement reinforced with geogrid. Journal of Engineering Sciences, pp. 1336-1348.

[9] Gupta, A. - Kumar, A. (2014): Comparative structural analysis of flexible pavements using finite element method. The International Journal of Pavement Engineering and Asphalt Technology, pp. 11-19.

https://doi.org/10.2478/ijpeat-2013-0005

[10] Hicks, R. G. - Monismith, C. L. (1971): Factors influencing the resilient response of granular materials. Highway research record, Volume 345. Record URL: http://onlinepubs.trb.org/Onlinepubs/hrr/1971/345/345-002.pdf

[11] Hjelmstad, D. K. - Kim, J. - Zuo, H. Q. (1997): Finite Element Procedures for Three-dimensional Pavement Analysis, Seatttle: ASCE.

[12] Hjelmstad, K. D. - Taciroglu, E. (1997): Coupled hyperelastic constitutive model for resilient response of granular materials. N.Y., Proceedings of the Airfield Pavement Conference.

[13] Kuo, C.-M. - Chou, F.-J. (2004): Development of 3-D Finite Element model for flexible pavements. Journal of the Chinese Institute of Engineers, 27(5), pp. 707-717. https://doi.org/10.1080/02533839.2004.9670918
[14] Li, M. - Wang, H. - Xu, G. - Xie, P. (2017): Finite element modeling and parametric analysis of viscoelastic and nonlinear pavement responses under dynamic FWD loading. Construction and Building Materials, Volume 141, pp. 23-35. https://doi.org/10.1016/j.conbuildmat.2017.02.096

[15] Mejłun, Ł. - Judycki, J. - Dołżycki, B. (2016): Comparison of elastic and viscoelastic analysis of asphalt pavement at high temperature. Vilnius, Modern Building Materials, Structures and Techniques. https://doi.org/10.1016/j.proeng.2017.02.095

[16] Pronk, A. C. (2005): The Huet-Sayegh model; A simple and excellent rheological model for master curves of asphalt mixes. Louisiana, American Society of Civil Engineers. https://doi.org/10.1061/40825(185)8

[17] Seed, B. H. - Mitry, G. F. - Monismith, C. L. - Chan, K. C., (1967): Prediction of flexible pavement deflections from laboratory repeated load tests, Washington D.C.: Transportation Research Board. Order URL: http://worldcat.org/issn/00775614

[18] Shayesteh, A. - Ghasemisalehabadi, E. - Khordehbinan, M. W. - Roastmi, T. (2017): Finite Element Method in Statistical Analysis of Flexible pavement. Journal of Marine Science and Technology, 25(2), pp. 142-15. 10.6119/JMST-016-0721-1

[19] Srikanth, R. M. (2015): Study on Analysis of Flexible Pavement using Finite Element based Software Tool. International Journal of Engineering Research \& Technology, 4(9), pp. 912-916. https://doi.org/10.17577/ijertv4is090865

[20] Sukumaran, B. et al. (2004): Three dimensional Finite Element modeling of flexible pavements. Atlantic city, FAA Worldwide airport technology transfer. https://doi.org/10.1061/40776(155)7

[21] Szydłowski, C. - Górski, J. - Stienss, M. - Smakosz, Ł. (2018): Numerical simulation of asphalt mixtures fracture using continuum models. s.l., AIP Conference Proceedings 1922. https://doi.org/10.1063/1.5019142

[22] Uzan, J. (1985): Characterization of Granular Material, Washington D.C.: Transportation Research Record.

[23] Zhang, J. - Yang, J. (2013): Advances in micromechanical constitutive theories and modeling. China, Procedia-Social and Behavioral Sciences 96, pp. 1304-1314. https://doi.org/10.1016/j.sbspro.2013.08.148

\section{Végeselem modellezés használata mechanikus pályaszerkezet-méretezéshez. Áttekintés: a modell felépítésétől az anyag valódi összetettségéig}

A végeselem modellezést (VEM) számos tudományos területen alkalmazzák. A VEM a szerkezeti vizsgálatok területén rendkívül megalapozott, de az aszfaltburkolatú útpályaszerkezetek méretezése terén is egyre gyakrabban merül fel az alkalmazása, sốt, ahogy a szerkezet terhelésre adott reakcióinak becslése a pályaszerkezetméretezés alapvetô összetevôje, a véges elemmel végzett precíz modellezések egyre fontosabbá válnak. A cikk a VEM pályaszerkezet-méretezés során való alkalmazásairól ad összefoglalást, az egyes szerkezeti rétegeknek a modellben való felépíthetôségére fókuszálva. A cikk célja emellett felhívni a figyelmet a VEM-ben rejlô lehetôségekre, miközben a VEM erôsségei mellett rámutat annak gyengeségeire is.

Kulcsszavak: végeselem módszer, aszfaltburkolat modellezése, anyagmodell

Ref.

Cho, Seoyoung - Tóth, Csaba - Soós, Zoltán: Finite Element Method analysis for mechanistic design in flexible pavement, Review: From how to build a material in FE analysis to complexity in reality Építőanyag - Journal of Silicate Based and Composite Materials, Vol. 70, No. 6 (2018), 204-208. p. https://doi.org/10.14382/epitoanyag-jsbcm.2018.35 